\title{
Assessment of Investment Process for Producing Copper Hollow Spheres
}

\author{
Seung-Boo Jung, Shae K. Kim and Young-Jig Kim \\ Sungkyunkwan University, 300 Chunchun-dong Jangan-gu, Suwon, Gyeonggi-do 440-746, Korea
}

The aim of the present paper is to demonstrate the feasibility of investment process in producing single-cell materials (hollow spheres) from copper alloys. Spheres were formed from $\mathrm{Cu}_{2} \mathrm{O}$ powders by the conventional investment shell mold manufacturing process of investment casting and then reduced to metallic copper hollow spheres in a hydrogen atmosphere. Optimum processing variables such as slurry viscosity were investigated and the mass ratio, hardness, and electrical conductivity of the hollow spheres were evaluated with respect to oxide reduction temperature and $\mathrm{ZnO}$ content.

(Received October 19, 2001; Accepted December 3, 2001)

Keywords: cellular material, hollow sphere, investment process, copper, $\mathrm{Cu}_{2} \mathrm{O}, \mathrm{ZnO}$

\section{Introduction}

Cellular materials and designed porous materials are a class of materials with extremely low densities and an outstanding combination of mechanical, electrical, thermal, and acoustic properties, based on nature's way of decreasing the weight of materials such as bone or cork by incorporating cells or pores. These materials are increasingly being considered as lightweight construction, heat exchangers, passive safety and other purposes. Especially, their extraordinary property combinations make them interesting for applications where more than one function is required e.g. high stiffness and fire resistance or acoustic damping.

Cellular (or porous) materials are defined as solids containing cells (or pores). They can be classified by morphology and dimensionality as well as formation mechanism, namely; by building up single cells (hollow spheres) or by incorporating cells into bulk material (foam materials). Both approaches lead to three-dimensional cellular materials but with different macroscopic properties, which are determined more by the cell formation mechanism. It is regarded that cellular materials produced by building up hollow spheres give predictable macroscopic properties, compared with those by foaming processes. ${ }^{1-5)}$

To date, hollow metallic spheres have been produced usually via the coaxial nozzle process using oxide slurry. ${ }^{6,7)}$ Compared with the conventional coaxial nozzle process, this paper demonstrates the feasibility of investment process in producing hollow spheres from copper alloys. Optimum processing variables such as slurry viscosity and the mass ratio, hardness, and electrical conductivity of copper hollow spheres with respect to oxide reduction temperature and $\mathrm{ZnO}$ content are discussed.

\section{Experimental Procedures}

The conventional investment shell mold manufacturing process ${ }^{8)}$ was utilized to make copper-based hollow spheres of various diameters and wall thickness. The polystyrene pattern sphere of desired diameter was dip-coated with a slurry containing a solvent (water or acetone according to binder), copper oxide $\mathrm{Cu}_{2} \mathrm{O}$ powders and a binder. After that, it was
Table 1 Types of binders examined.

\begin{tabular}{ccc}
\hline Binder & Manufacturing company & Solvent \\
\hline PVA & Yakuri pure chemicals & \\
\cline { 1 - 2 } PG & Shinyo pure chemicals & Water \\
\hline PA & Showa chemicals & \\
\hline PMMA & Acros organics & Acetone \\
\hline CA & Kanto chemicals & \\
\hline
\end{tabular}

dried, and then dipped and dried again. Dipping and drying procedures were repeated until the desired wall thickness of hollow sphere was obtained. To improve and/or control shell strength, which finally determines the properties of reduced copper hollow spheres, zinc oxide $\mathrm{ZnO}$ powders were added to the slurry containing $\mathrm{Cu}_{2} \mathrm{O}$ powders and the effect of $\mathrm{ZnO}$ amount on the properties of reduced copper hollow spheres were investigated. The invested shell was dried at a controlled temperature of $22^{\circ} \mathrm{C}$ with a relative humidity of $50 \pm 10 \%$ for $5 \mathrm{~h}$. This was followed by polystyrene leaching and then reducing in a hydrogen atmosphere at various temperatures. Binders tested are shown in Table 1. As given in Table 2, the viscosities of various slurries were measured using an LVDV-I+ viscometer.

\section{Results and Discussion}

In Table 2, the viscosities of various slurries are given with respect to the mass ratio of $\mathrm{Cu}_{2} \mathrm{O}$ powders to solvent (water or acetone) and binder. When the ratio of $\mathrm{Cu}_{2} \mathrm{O}$ powders to solvent was $8: 2$, it was impossible to mix the powders with the solvent regardless of the amount of binder. On the other hand, when the ratio was 6:4 especially in the case of water, the viscosity of the slurry was too low even with 5 mass\% of binder added to the slurry. The acetone based slurries with 3 mass $\%$ of binder were mainly utilized although they showed difficulty in sustaining and controlling viscosity during the process due to the sublimation of acetone.

Figure 1 shows copper hollow spheres produced by the conventional investment shell mold manufacturing process of investment casting. Depending on the size of polystyrene 
Table 2 Viscosities of various slurries with respect to the mixing ratio and the mass percent of binder added (unit: $\mathrm{mPa} \cdot \mathrm{s}$ ).

\begin{tabular}{|c|c|c|c|c|c|}
\hline \multirow{2}{*}{ Binder } & \multirow{2}{*}{$\begin{array}{c}\text { Mixing } \\
\text { ratio }\end{array}$} & \multicolumn{3}{|c|}{ Mass $\%$ of binder } & \multirow{2}{*}{ Solvent } \\
\hline & & 1 & 3 & 7 & \\
\hline \multirow{2}{*}{ PVA } & 7 to 3 & $\mathrm{~L}$ & 300 & 1345 & \multirow{5}{*}{ Water } \\
\hline & 8 to 2 & $X$ & $\mathrm{X}$ & $\mathrm{X}$ & \\
\hline PG & 7 to 3 & 1250 & 990 & 870 & \\
\hline \multirow{2}{*}{$\mathrm{PA}$} & 6 to 4 & 4150 & $\mathrm{X}$ & $\mathrm{X}$ & \\
\hline & 7 to 3 & 8100 & $\mathrm{X}$ & $\mathrm{X}$ & \\
\hline \multirow{3}{*}{ PMMA } & 6 to 4 & $\mathrm{~L}$ & $\mathrm{~L}$ & 380 & \multirow{6}{*}{ Acetone } \\
\hline & 7 to 3 & $\mathrm{~L}$ & 170 & 13000 & \\
\hline & 8 to 2 & 1200 & $X$ & $\mathrm{X}$ & \\
\hline \multirow{3}{*}{$\mathrm{CA}$} & 6 to 4 & $\mathrm{~L}$ & 235 & 2870 & \\
\hline & 7 to 3 & 290 & 3500 & 33500 & \\
\hline & 8 to 2 & 2150 & $\mathrm{X}$ & $\mathrm{X}$ & \\
\hline
\end{tabular}

L: too low to be measured

$\mathrm{X}$ : too thick for $\mathrm{Cu}_{2} \mathrm{O}$ powders to be incorporated into the solvent

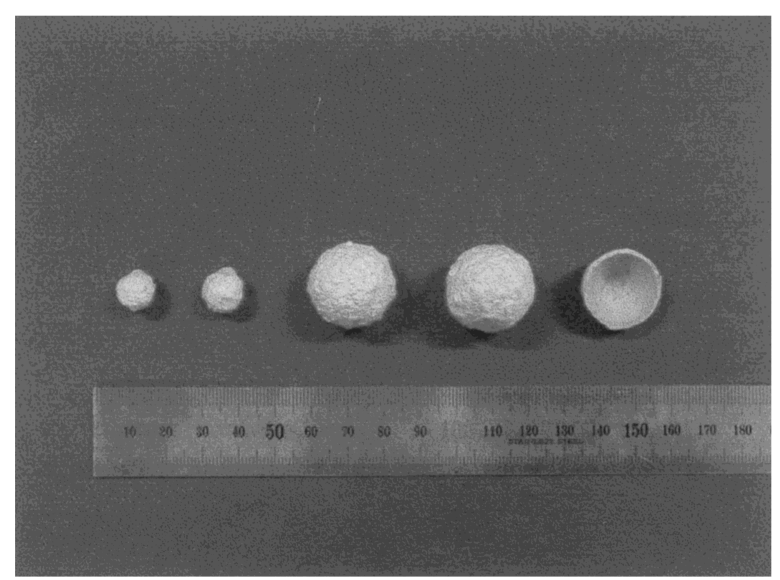

Fig. 1 Photograph showing copper hollow spheres produced.

pattern spheres and processing parameters, sphere diameters from $1 \mathrm{~mm}$ to hundreds of millimeters can be obtained and the range of sphere wall thickness typically achieved can be 0.2 to $5 \mathrm{~mm}$. Compared with the conventional coaxial nozzle process, the range of control over diameter and wall thickness can be greatly enlarged, and furthermore, the properties of copper hollow spheres can be tailored by dipping in different or functionally graded slurries.

Figure 2 shows the mass ratio of copper hollow spheres before and after the oxide reduction. It is seen that the mass ratio decreases with increasing reduction temperature and $\mathrm{ZnO}$ content. As the hydrogen reducing temperature increases, the effect of $\mathrm{ZnO}$ content on the mass ratio becomes visible due to complete reduction of $\mathrm{ZnO}$. Compared with $\mathrm{Cu}_{2} \mathrm{O}, \mathrm{ZnO}$ is not easily reduced even in a hydrogen atmosphere, unless the hydrogen pressure is much higher than atmospheric pressure at relatively low temperatures, e.g. $650^{\circ} \mathrm{C}$. However $\mathrm{ZnO}$ can be reduced to $\mathrm{Zn}$ at around $950^{\circ} \mathrm{C}$ in a hydrogen atmosphere of near $1 \mathrm{~atm}$, as generally stated by the effect of $P_{\mathrm{H}_{2}} / P_{\mathrm{H}_{2} \mathrm{O}}$ on oxide reduction in thermodynamics data. ${ }^{9)}$ Therefore, copper hollow spheres produced from the slurry with high $\mathrm{ZnO}$ con-

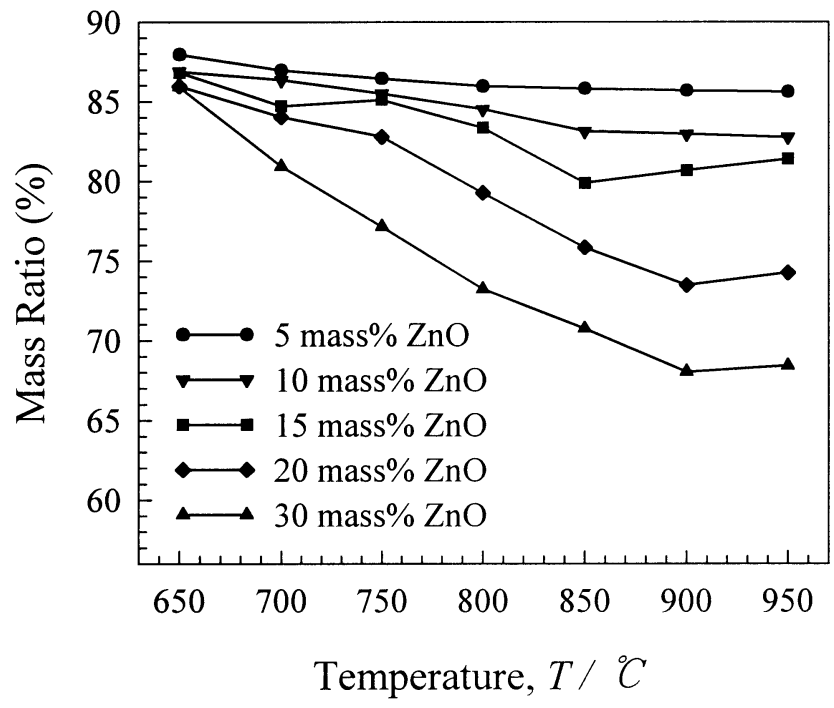

Fig. 2 Dependence of the mass ratio of copper hollow spheres before and after the oxide reduction on $\mathrm{ZnO}$ content and oxide reduction temperature.

tent have relatively low densities after complete reduction due to the difference in density between copper $\left(8960 \mathrm{~kg} / \mathrm{m}^{3}\right)$ and zinc $\left(7140 \mathrm{~kg} / / \mathrm{m}^{3}\right)$.

Figure 3 shows the hardness values of copper hollow spheres. As expected, the hardness of copper hollow spheres increases with increasing reduction temperature. At low reduction temperatures the hardness is inversely proportional to $\mathrm{ZnO}$ content while the effect of $\mathrm{ZnO}$ on the hardness becomes insignificant at high temperatures. The results can be explained by two facts: (1) $\mathrm{ZnO}$ content, which determines the final composition of copper hollow spheres reduced, does not affect the hardness much, just as the hardness does not vary much with $\mathrm{Zn}$ content in $\mathrm{Cu}-\mathrm{Zn}$ binary alloys; ${ }^{10)}$ and (2) the hardness depends mainly on reduction temperature, which determines the amount of copper and zinc reduced, based on the discussion for the result of Fig. 2. Therefore, the difference in hardness at low reduction temperatures should not be understood by the effect of $\mathrm{ZnO}$ content, but by the effect of $P_{\mathrm{H}_{2}} / P_{\mathrm{H}_{2} \mathrm{O}}$ on $\mathrm{Cu}_{2} \mathrm{O}$ and $\mathrm{ZnO}$ reduction. However, it is worth noting that the hardness of copper hollow spheres reduced at $950^{\circ} \mathrm{C}$ is comparable to those of the same compositional $\mathrm{Cu}-\mathrm{Zn}$ alloys in cold-worked and tempered condition (100$110 \mathrm{HV}) .{ }^{10)}$

Figure 4 shows the electrical conductivity (\%IACS, International Annealed Copper Standard) of copper hollow spheres. It is clearly seen that the \%IACS depends on reduction temperature, but as generally acknowledged, at high hydrogen reducing temperatures, the \%IACS is also determined by $\mathrm{ZnO}$ content.

Important point to deduce from Figs. 3 and 4 is that the hardness and \%IACS can be controlled by oxide reduction temperature and $\mathrm{ZnO}$ content.

\section{Conclusion}

Investment process represents a method for processing hollow spheres, which subsequently can be joined together to form a cellular structure. The present results clearly show that copper hollow spheres can be produced with the range 


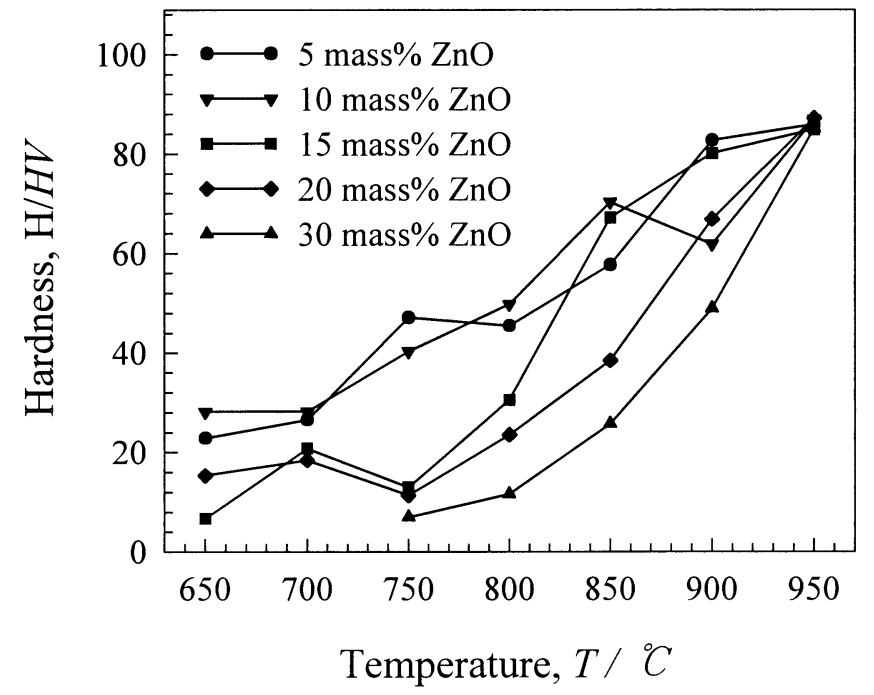

Fig. 3 Dependence of the hardness of copper hollow spheres on $\mathrm{ZnO}$ content and oxide reduction temperature.

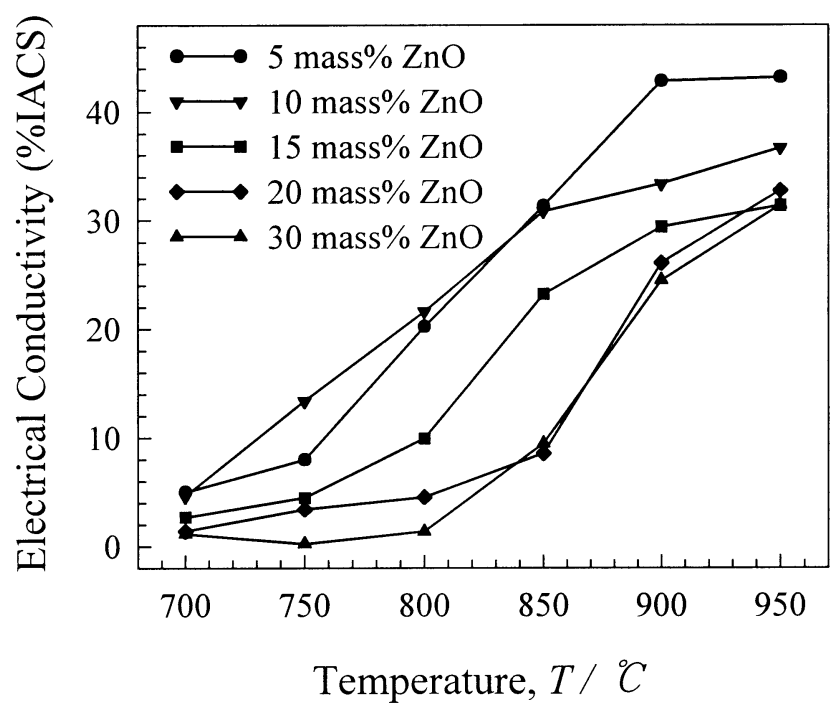

Fig. 4 Dependence of the \%IACS of copper hollow spheres on $\mathrm{ZnO}$ content and oxide reduction temperature. of control over diameter and wall thickness, depending upon the size of polystyrene pattern spheres and processing parameters. The hardness and \%IACS of copper hollow spheres can be controlled by oxide reduction temperature and $\mathrm{ZnO}$ content. We believe that this method will gain importance in future since controlling the cell formation is important for properties, which in turn form the basis for new and successful applications of cellular materials.

\section{REFERENCES}

1) L. J. Gibson and M. F. Ashby: Cellular Solids-Structure and Properties $2^{\text {nd }} E d$., (Cambridge University Press, Cambridge, 1997) pp. 1-510.

2) K. Ishisaki, S. Komarneni and M. Nanko: Porous Materials, (Kluwer Academic Publishers, Dordrecht, 1998) pp. 1-240.

3) Ken Easterling: Tomorrow's Materials, (The Institute of Materials, London, 1993) pp. 1-42.

4) J. Banhart: Proc. Metal Foam Symposium, ed. by J. Banhart and H Eifert, (Verlag Metall Innovation Technologie MIT, Bremen, 1997) pp. 3-12.

5) R. Neugebauer, H. Braunlich and U. Wagner: Proc. MRS "Porous and Cellular Materials for Structural Applications" Symposium Vol. 521, (Materials Research Society, Warrendale, PA, 1998) pp. 271-280.

6) L. B. Torobin: US Patent 4, 777, 154 (1988).

7) K. M. Hurysz, J. L. Clark, A. R. Nagel, C. U. Hardwicke, K. J. Lee, J. K. Cochran and T. H. Sanders Jr.: Proc. MRS "Porous and Cellular Materials for Structural Applications" Symposium Vol. 521, (Materials Research Society, Warrendale, PA, 1998) pp. 191-203.

8) G. J. Cavies: Solidification and Casting, (Applied Science Publishers, London, 1973) pp. 135-165.

9) D. V. Gaskell: Introduction to Metallurgical Thermodynamics $2^{\text {nd }}$ Ed., (Hemisphere Publishing, NY, 1981) pp. 261-318.

10) P. Robinson: Metals Handbook Vol. $210^{\text {th }}$ Ed., (ASM International, Materials Park, OH, 1990) pp. 265-355. 